\title{
Current investigations into the early Neolithic of the Zagros foothills of Iraqi Kurdistan
}

Book or Report Section

Published Version

Matthews, R., Matthews, W., Raheem, K. R. and Aziz, K. R. (2016) Current investigations into the early Neolithic of the Zagros foothills of Iraqi Kurdistan. In: Kopanias, K. and MacGinnis, J. (eds.) The Archaeology of the Kurdistan Region of Iraq and Adjacent Regions. Archaeopress, Oxford, pp. 219228. ISBN 9781784913939 Available at http://centaur.reading.ac.uk/66014/

It is advisable to refer to the publisher's version if you intend to cite from the work. See Guidance on citing.

Publisher: Archaeopress

All outputs in CentAUR are protected by Intellectual Property Rights law, including copyright law. Copyright and IPR is retained by the creators or other 
copyright holders. Terms and conditions for use of this material are defined in the End User Agreement.

\section{www.reading.ac.uk/centaur}

\section{CentAUR}

Central Archive at the University of Reading

Reading's research outputs online 


\section{THE ARCHAEOLOGY OF THE KURDISTAN REGION OF IRAQAND ADJACENT REGIONS}

Edited by

\section{Konstantinos Kopanias and John MacGinnis}




\section{ARCHAEOPRESS PUBLISHING LTD \\ Gordon House \\ 276 Banbury Road \\ Oxford OX2 7ED}

www.archaeopress.com

ISBN 9781784913939

ISBN 9781784913946 (e-Pdf)

(C) Archaeopress and the authors 2016

Cover illustration: Erbil Citadel, photo Jack Pascal

All rights reserved. No part of this book may be reproduced, in any form or by any means, electronic, mechanical, photocopying or otherwise, without the prior written permission of the copyright owners.

Printed in England by Holywell Press, Oxford

This book is available direct from Archaeopress or from our website www.archaeopress.com 


\section{Contents}

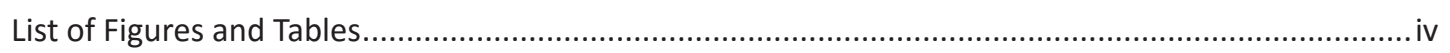

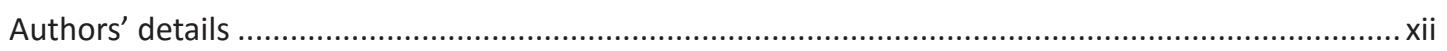

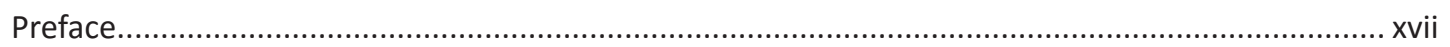

Archaeological investigations on the Citadel of Erbil: Background, Framework and Results............. 1 Dara AL YAQOOBI, Abdullah KHORSHEED KHADER, Sangar MOHAMMED,

Saber HASSAN HUSSEIN, Mary SHEPPERSON and JOhn MACGINNIS

The site of Bazyan: historical and archaeological investigations.

Narmin AMIN ALI and Vincent DEROCHE

Short notes on Chalcolithic pottery research: The pottery sequences of Tell Nader (Erbil) and Ashur (Qal'at Sherqat)

Claudia BEUGER

New Evidence of Paleolithic Occupation in the Western Zagros foothills: Preliminary report of cave and rockshelter survey in the Sar Qaleh Plain in the West of Kermanshah Province, Iran

Fereidoun BIGLARI and SOnia SHIDRANG

Activities of Sapienza-University of Rome in Iraqi Kurdistan: Erbil, Sulaimaniyah and Duhok .49

Carlo Giovanni CERETI and LuCa COLLIVA

The Achaemenid Period Occupation at Tell ed-Daim in Iraqi Kurdistan

John CURTIS and Farouk AL-RAWI

'Inscription D' from Sennacherib's Aqueduct At Jerwān: Further Data and Insights. .65

Frederick Mario FALES and Roswitha DEL FABBRO

The Land of Nineveh Archaeological Project: A Preliminary Overview on the Pottery and

Settlement Patterns of the 3rd Millennium BC in the Northern Region of Iraqi Kurdistan 75 Katia GAVAGNIN

Animal husbandry and other human-animal interactions in Late Ubaid-Early Uruk northern Iraq: the faunal remains from the $\mathbf{2 0 1 2}$ excavation season at Tell Nader Angelos HADJIKOUMIS

Hawsh-Kori and Char-Ghapi: Why the Sassanids built two monuments in the west of Kermanshah and the south of Iraqi Kurdistan 101 Ali HOZHABRI

Across millennia of occupation: the Land of Nineveh Archaeological project in Iraqi Kurdistan: The prehistory and protohistory of the Upper Tigris rediscovered 125 Marco IAMONI

The Iraqi Institute: Education for Archaeological Research and Conservation

Jessica JOHNSON, Abdullah KHORSHEED and Brian Michael LIONE 
Excavations of the Chalcolithic Occupations at Salat Tepe on the Upper Tigris, Southeastern Anatolia

Tatsundo KOIZUMI, Minoru YONEDA, Shigeru ITOH and Koichi KOBAYASHI

Insights into the settlement history of Iraqi Kurdistan from the Upper Greater Zab

Archaeological Reconnaissance Project

Rafał KOLIŃSKI

Two Ottoman Trade Buildings (Qaisariya) in the Bazaar of Erbil from Building Archaeology to Refurbishment Planning

Dietmar KURAPKAT

Ninevite $\mathbf{5}$ - culture or regional pottery style?

Dorota ŁAWECKA

Back to the Land of Mușașir/Ardini: Preliminary report on fieldwork (2005-2012)

Dlshad MARF

New Researches on the Assyrian Heartland: The Bash Tapa Excavation Project

Lionel MARTI and Christophe NICOLLE

Materials from French Excavations in Erbil Area (2011-2013): Qasr Shemamok

Maria Grazia MASETTI-ROUAULT and Ilaria CALINI

Current Investigations into the Early Neolithic of the Zagros Foothills of Iraqi Kurdistan.

Roger MATTHEWS, Wendy MATTHEWS and Kamal Rasheed RAHEEM

About Bakr Awa

Peter A. MIGLUS

Magnetic investigations in the Shahrizor Plain: Revealing the unseen in survey prospections

Simone MüHL and Jörg FASSBINDER

The Bazaar of Erbil within the Context of Islamic Trade Routes and Trade Buildings

Martina MüLleR-WIENER and Anne MOLLENHAUER

Halaf Settlement in the Iraqi Kurdistan: the Shahrizor Survey Project

Olivier NIEUWENHUYSE, Takahiro ODAKA and Simone MüHL

Contextualizing Arbīl: Medieval urbanism in Adiabene

Karel NOVÁČEK

Filling the Gap: The Upper Tigris Region from the Fall of Nineveh to the Sasanians.

Archaeological and Historical Overview Through the Data of the Land of

Nineveh Archaeological Project.

ROCCO PALERMO

Satu Qala: an Assessment of the Stratigraphy of the Site

Cinzia PAPPI 
Helawa: A New Northern Ubaid/Late Chalcolithic Site in the Erbil Plain

Luca PEYRONEL, Agnese VACCA and Gioia ZENONI

From the banks of the Upper Tigris River to the Zagros Highlands. The first season (2013) of the Tübingen Eastern Habur Archaeological Survey

Peter PFÄLZNER and Paola SCONZO

Gre Amer, Batman, on the Upper Tigris: A Rescue Project in the Ilısu Dam Reservoir in Turkey.

Gül PULHAN and StUart BLAYLOCK

In the Neo-Assyrian Border March of the Palace Herald: Geophysical Survey and Salvage Excavations at Gird-i Bazar and Qalat-i Dinka (Peshdar Plain Project 2015)

Karen RADNER, Andrei AŠANDULESEI, Jörg FASSBINDER, Tina GREENFIELD, Jean-Jacques HERR, JanOscha KREPPNER and Andrea SQUITIERI

New investigations at Shanidar Cave, Iraqi Kurdistan

Tim REYNolds, William BoIsMier, Lucy FARR, Chris Hunt, Dlshad ABDUlmutalB and Graeme BARKER

Materials from French excavations in the Erbil area (2010): Kilik Mishik 373

Olivier ROUAULT and Ilaria CALINI

Kurd Qaburstan, A Second Millennium BC Urban Site: First Results of the Johns Hopkins Project 385

Glenn M. SCHWARTZ

The Sirwan (Upper Diyala) Regional Project - First Results

Tevfik Emre ŞERIFOĞLU, Claudia GLATZ, Jesse CASANA and Shwkr MuHAMMED HAYDAR

Tracking early urbanism in the hilly flanks of Mesopotamia - three years of

Danish archaeological investigations on the Rania Plain

Tim Boaz Bruun SKULDBøL and Carlo COLANTONI

The Activities of the Italian Archaeological Mission in Iraqi Kurdistan (MAIKI):

The survey area and the new evidence from Paikuli blocks documentation

Gianfilippo TERRIBILI and Alessandro TILIA

The Kani Shaie Archaeological Project

André TOMÉ, Ricardo CABRAL and Steve RENETTE

Philological and scientific analyses of cuneiform tablets housed in

Sulaimaniya (Slemani) Museum

Chikako WATANABE

'Carrying the glory of the great battle'. The Gaugamela battlefield: ancient sources, modern views, and topographical problems.

Kleanthis ZOUBOULAKIS 


\title{
Current Investigations into the Early Neolithic of the Zagros Foothills of Iraqi Kurdistan
}

\author{
Roger Matthews, Wendy Matthews, Kamal Rasheed Raheem \\ and Kamal Rauf AzIz
}

\section{Sedentism and resource management in the Neolithic of the Central Zagros}

One of the most significant transformations in history took place after the last Ice Age, from c. 12,000 BC (all dates calibrated $\mathrm{BC}$ ), when human communities changed from being mobile hunter-foragers to more settled farmers and stock-keepers, with domesticated crops and animals. This Neolithic transformation was a fundamental development in the human condition across much of the world and led ultimately, through surplus accumulation and social differentiation, to the emergence of towns, cities, and empires, shaping the modern world.

Neolithic developments occurred very early in Southwest Asia. In recent decades there has been much work on Neolithic developments in this region through excavations in Turkey, the northern plains of Iraq, Syria, Jordan, and the Levant, which have together demonstrated great variability in local trajectories of development from hunter-forager to villager-farmer. By contrast, one area that until recently has been little investigated since the 1970s is the Zagros Mountain region and hilly flanks of western Iran and eastern Iraq, the so-called eastern Fertile Crescent. Earlier work in this region was of key importance in developing studies of the Neolithic transformation, with excavations at sites such as Jarmo, Asiab, Sarab, Ali Kosh, and Ganj Dareh in the 1950s-70s (Braidwood and Howe 1960; Hole et al. 1969; Smith 1990). These researches indicated that Neolithic communities changed to sedentary lifestyles and began using fired ceramics, the earliest in Southwest Asia, by c. 7900 BC at sites such as Ganj Dareh in western Iran. Study of the plant and animal remains indicates that the earliest Neolithic communities in the Zagros favoured use of lentils, peas, and nuts over cereals, that wild goat were intensively hunted, and there is evidence for domestication of goat by c. 7900 BC (Zeder 2006).

For approximately 25 years after 1979 , there was almost no fieldwork concerning the Neolithic of the eastern Fertile Crescent, and there is less up to date evidence compared to the rest of Southwest Asia and beyond. A wide range of more recent studies, however, is steadily correcting this imbalance (Matthews and Fazeli Nashli 2013; Riehl et al. 2013). The Central Zagros Archaeological Project (CZAP) is a collaborative programme, whose main partners are the University of Reading, Sulaimaniyah and
Erbil Antiquities Directorates, Bu Ali Sina University, Hamedan, and the Iranian Centre for Archaeological Research. The objectives are to investigate research questions within the Early Neolithic of the Central Zagros region. What was the nature of early sedentism and how did it develop from temporary and seasonal to permanent and year-round? How was architecture constructed and how was early village space used and socialised? What was the role of ritual and human burial in social cohesion at this time? What modes of animal husbandry were employed, including intensive hunting, herding, management and domestication of goats, native in the wild to the Zagros? What plant resources were exploited and how? What is the absolute chronology of development in the Zagros Neolithic? These and many other questions are being addressed by excavation and inter-disciplinary analysis at four sites on a transect from the lowland to the highland Zagros, in order to study local and regional variation in the development of the Neolithic (Fig. 1). In the lowland piedmont zone in Iraqi Kurdistan, the sites comprise Bestansur and Shimshara as well as regional survey in Zarzi valley. In the highland zone, the sites comprise Sheikh-e Abad and Jani in the Central Zagros region of western Iran (Matthews et al. 2013; Matthews and Fazeli Nashli 2013).

The analyses and results from this research, involving the application of inter-disciplinary approaches to archaeological questions, are of value in situating the Central Zagros within the Neolithic transformation in Southwest Asia. The research assists in placing our own species within a rich context of ecological and social change that characterised the Neolithic transformation following the end of the last Ice Age, one of the most impactful episodes in human history.

Research questions: an agenda for research into the Early Neolithic of the eastern Fertile Crescent

\section{Climate and environment}

The importance of climate and environment has been re-emphasised in recent research on the Neolithic more widely as significant factors in spatial and temporal variability in biomes and thereby in the histories of early sedentism and the inter-relationships between humans, plants and animals (Zeder 2011). There is increasing evidence for local and regional variation in environment 


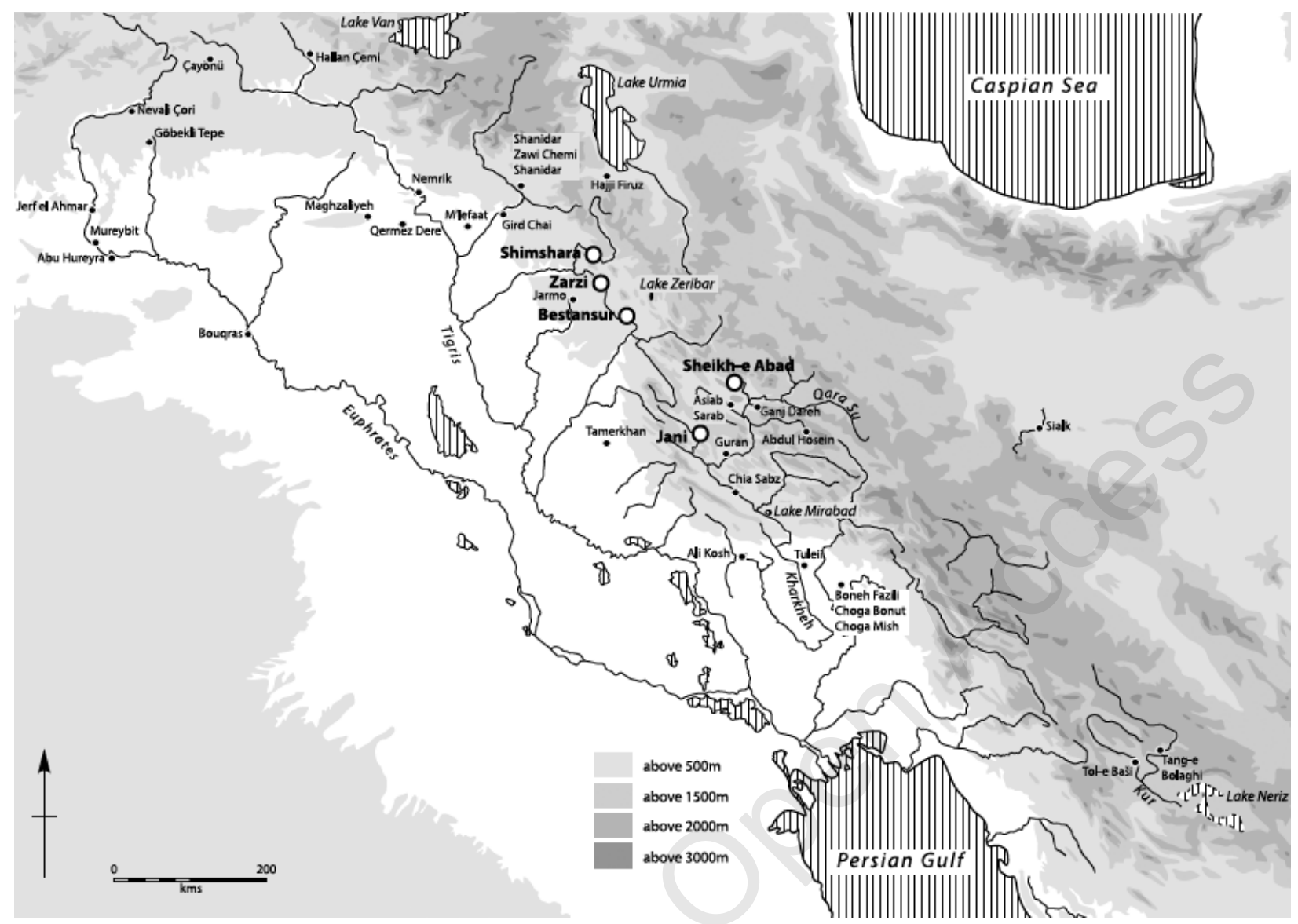

FiguRE 1. MAP TO SHOW LOCATION OF KEY CZAP SITES.

and ecological strategies in the development of villages and agriculture across Southwest Asia, as well as globally (Willcox 2005), and in the choices made by specific communities.

Current interpretations of lake cores from Lake Zeribar, $45 \mathrm{~km}$ to the east of Bestansur, suggest the environment included grasslands and pistachio and almond trees in the Zagros region in the Early Holocene (Wasylikowa and Witkowski 2008). There needs to be inter-disciplinary investigation of the specific trajectories of environmental interaction followed by human communities in the Zagros region. Within the remit of CZAP, initial research has begun through collection of speleothem palaeoclimate records from local cave sites in the Iraqi Zagros, for study under the direction of Professor Dominik Fleitmann of the University of Reading in collaboration with Dr Mark Altaweel of UCL.

\section{Sedentism}

The issue of how communities become more sedentary through the Early Holocene is one of the fundamental research issues for the Neolithic period. The extent to which initial activities at Central Zagros Neolithic sites were associated with periodic hunting/gathering or with year-round settlement remains to be established. It is likely that there was periodic fission and fusion of populations in order to obtain and share resources and to socialise, as increasingly evident at other sites in Southwest Asia. High-resolution microstratigraphic and micro-archaeological evidence is being recovered and examined from CZAP sites in order to investigate the nature, seasonality and periodicity of activities.

\section{Social roles and relations}

As yet we know little about the nature of social organisation in Early Neolithic communities of the eastern Fertile Crescent. Was the household a key social unit, as studies of Neolithic sites in other regions have suggested (Kuijt 2000), or is there evidence of varying social units and networks as emerging at a number of sites, such as Çatalhöyük? How was space structured and organised at short and longer term timescales, 
and what indicators are there of social actions, roles and interaction and exclusion during the life-cycle of individual features, spaces and buildings across the community and generations, at the scale of single deposits, sequences, site levels and the history of the settlement? These questions are being addressed through targeted excavation of intact Early Neolithic deposits, in particular at the site of Bestansur in Iraqi Kurdistan.

\section{Technological choices and material cultural traditions}

There is considerable evidence for shared knowledge of materials and technology across Southwest Asia in the Neolithic as well as for local and regional variation. Material evidence from Neolithic sites of the region includes architecture, ground stone and chipped stone tools as well as special items that have clearly been traded or exchanged over considerable distances, such as beads of carnelian and sea-shell, and tools of obsidian. What were the socio-economic practices and trans-regional connections that underpinned such long-distance movements of materials? What choices were made at Bestansur and what was the site's role in innovation more widely?

\section{Symbolism and ritual}

Finally, we consider whether there are traces of ritual and activities such as feasting, which are often argued to have played a key role in Neolithic society and life-ways (Hodder 2010). Some have argued that the Neolithic of the eastern Fertile Crescent is rather lacking in evidence for elaborate cultic or ritual activity (Bernbeck 2004) but how valid is this interpretation in the light of recent work?

\section{Methods}

The main approach in CZAP in Iraqi Kurdistan is excavation at the Neolithic sites of Bestansur and Shimshara, to investigate socio-economic and cultural strategies through the Early Neolithic. Recording and processing are managed through the webbased Integrated Archaeological Data-Base (IADB). Excavation is being conducted, employing trenches for diachronic investigation and open-area trenches to examine buildings, external areas, middens and streets/ corridors. Excavated deposits are quantified, sieved, floated, sampled, and processed for recovery of lithics, ground-stone, clay tokens, figurines, faunal and botanical remains (macro and micro), phytoliths, molluses, and architectural materials.

A consistent methodology is applied in the excavation of all trenches at Bestansur and Shimshara. Excavations begin by removal of topsoil and upper eroded and wash deposits by large pick and shovels. At Bestansur, where most of our excavation has taken place, intact Neolithic deposits are encountered at depths of $30-50 \mathrm{~cm}$ below the modern field and mound surfaces. Excavation of these deposits proceeds with small pick and trowel with occasional use of large tools. We employ systematic sampling procedures, collecting $250 \mathrm{~g}$ archive samples and $50 \mathrm{l}$ whole-earth flotation samples from every context, where the deposits provide sufficient material. Additional samples are taken as required for a range of specialist purposes. Dry-sieving with $4 \mathrm{~mm}$ mesh is conducted on deposits once samples have been collected, except in cases where the heavy clay content of deposits makes dry-sieving unfeasible. In these cases a sample of the deposit is processed through dry-sieving and the remainder is shovelled into wheel-barrows and checked by hand before disposal on the spoil-heap, with a tally of buckets and barrows being maintained for each context. The local workmen are highly adept at hand recovery of the smallest fragments of cultural material from broken soil on the ground and in the wheel-barrow. All excavation and sampling activities are recorded on a range of forms for entry into the Integrated Archaeological Data-Base. At the end of each season all soundings are lined with organic sacking and back-filled with the original excavated material.

Additionally, intensive field survey has been conducted during 2013 in the vicinity of Zarzi cave, in the Iraqi Central Zagros, in order to investigate the prehistoric settlement of this fertile region.

\section{Excavations at Bestansur}

The mound of Bestansur is located $33 \mathrm{~km}$ southeast of Sulaimaniyah city, on the western edge of the Shahrizor Plain. The site was first located by Iraqi archaeologists and was more recently surveyed by a German team, catalogued as site number SSP6 and assigned to the Neolithic period on the basis of surface finds (Altaweel et al. 2012, 20-1). From our own work it is now clear that the upper layers of the mound belong to the Iron Age, in particular to the Neo-Assyrian period, and the Sassanian period. Preliminary excavations, by Dr Lisa Cooper of the University of British Columbia, of stone walls identified in geophysical survey in the fields to the southeast of the mound have revealed a significant NeoAssyrian destruction layer.

Preliminary surface walking and artefact collection in 2011-2012 of the mound at Bestansur and the fields surrounding the mound identified Neolithic chert and obsidian scatters over an area of c. $250 \mathrm{~m}$ around the visible mound, suggesting that intact Neolithic levels could be excavated in the fields on all sides of the mound. Guided by the surface finds and the mound's topography we have so far excavated 13 trenches, located on the lower slopes of the mound and in the surrounding fields (Fig. 2). Neolithic architecture was identified in nine of these 13 trenches. Five trenches (Trenches 7, 9, 10 


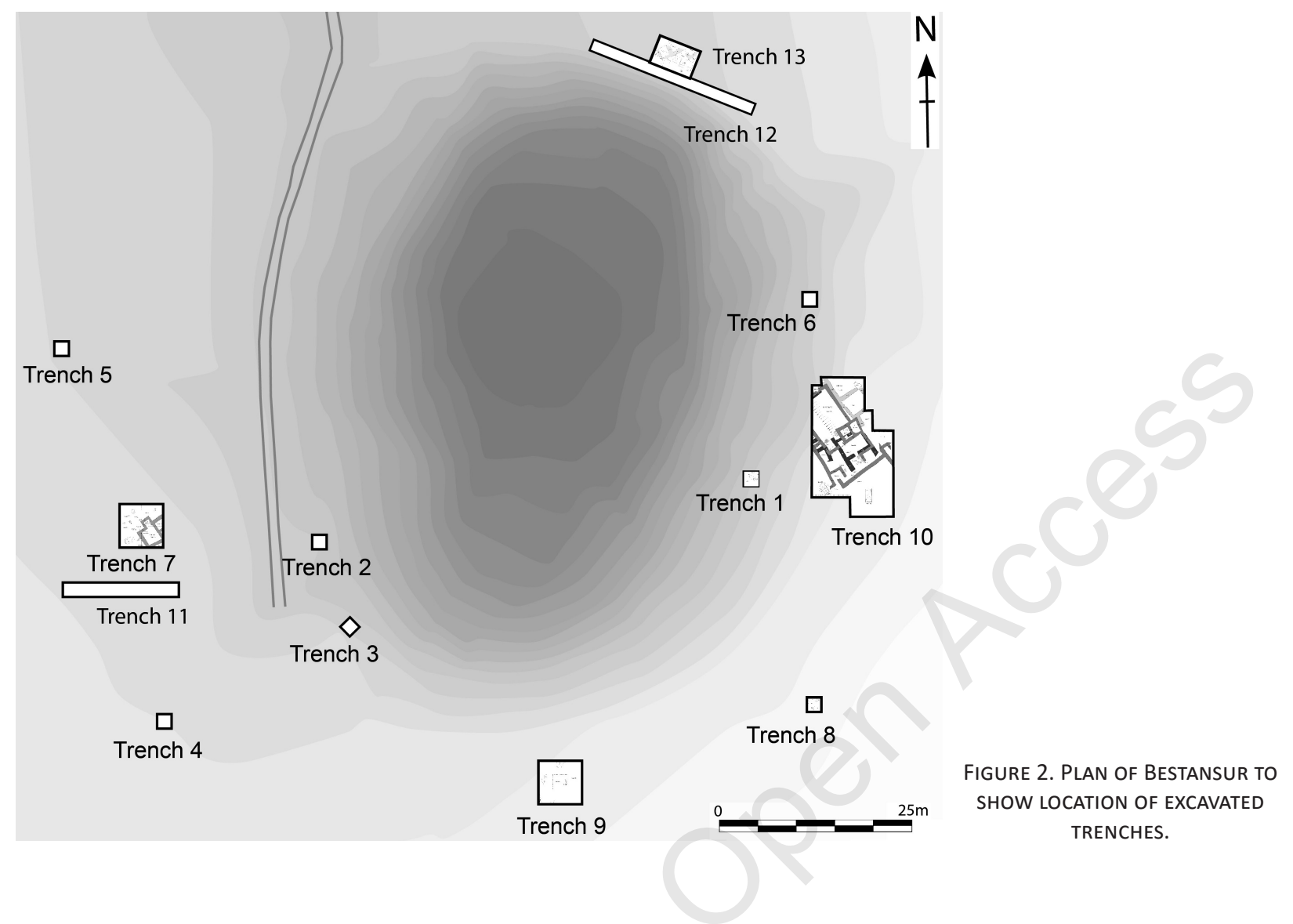

and 12-13) have been expanded in order to investigate extensive Neolithic deposits and structures.

As excavation proceeded it became clear that intact Neolithic deposits survive below the modern plough soil at almost all locations and are readily accessible for excavation. Considering the overall picture from all 13 trenches, intact Neolithic deposits are preserved across an excavated area of more than $100 \mathrm{~m}$ north-south and 100 $\mathrm{m}$ east-west, in fields on all sides of the archaeological mound and under the Iron Age mound too. If contiguous and contemporary, this spread of occupation indicates a Neolithic site of at least 1.0 hectare, but the precise limits of the surface lithic spread have yet to be defined and it is likely that the Neolithic site is significantly larger, possibly $>250 \mathrm{~m}$ in diameter. The modern surface in the fields slopes gently down from northwest to southeast.

Probable Neolithic deposits were also revealed in the base of the mound itself, in Trenches 1 and 2, in the form of deposits with Neolithic lithics and without later pottery. These basal levels without pottery, moreover, are similar in absolute height to intact Neolithic levels in the adjacent fields, further suggesting that they are Neolithic in date, at c. $93 \mathrm{~m}$ above site datum in the west in Trench
2, and at 92.13-92.05 $\mathrm{m}$ above site datum in the east in Trench 1. The similarity in absolute levels suggests the Neolithic site at Bestansur may have been relatively flat with a gentle northwest-southeast slope. This apparent flatness may be due to erosion and activities at the site since the Neolithic, including possible levelling for construction in later periods and modern ploughing. There could be a small Neolithic raised mound in the c. $52 \mathrm{~m}$ distance between Trenches 1 and 2, below the top of the current 7-10 m high mound, as suggested by Neolithic deposits in Trenches 12-13 which form at least the basal $1 \mathrm{~m}$ of this mound above the fields. Further excavations on the mound will continue to investigate the nature and date of occupation levels on the mound.

Although Neolithic ceramics were identified in survey at the northwest of the site (Nieuwenhuyse et al. 2012), the Neolithic deposits excavated in the fields around Bestansur all appear date to the Pre-Pottery Neolithic as no definitely identifiable sherds of Neolithic pottery have been recovered in excavation. The site appears to have been abandoned for a long time at some stage after the Neolithic, with a resumption of human presence at the site only in the Iron Age several millennia later. No Chalcolithic or Bronze Age materials were found 
at Bestansur, but the existence of Chalcolithic and Bronze Age sites in the vicinity of the site shows that the abandonment was local to the site and not part of a regional episode. Such shifts in precise settlement locations may have been connected with episodic movements of the major spring at Bestansur or of the river flowing from it. Future geomorphological and palaeo-environmental research in the area will address this and related questions.

\section{Bestansur, Trench 10 architecture}

Excavations in Trench 10, to the east of the mound, have revealed a cluster of multi-roomed buildings that form a Neolithic neighbourhood (Fig. 3). Radiocarbon dates from these structures and associated deposits firmly date them to $7700-7600 \mathrm{BC}$ (Fig. 4). The earliest building revealed in Trench 10 is Building 8, not yet excavated. This building is constructed of boat-shaped mud-bricks set in layers of mortar, and many of the wall faces are covered in multiple layers of fine plaster with some evidence for painting.

Building 5 in Trench 10 has been almost completely revealed and excavated. This structure is constructed of reddish-brown pisé with calcitic inclusions and many of the wall faces are also plastered. The layout of Building 5 is distinctive, with a large rectangular ante-room, Space 55, a stone threshold leading into the main room, Space 50, and smaller adjacent rooms. A very unusual large carved and incised stone (Fig. 5) was set against the wall face at one side of the entrance to the building. This stone was clearly used in craft activities involving repeating cutting with sharp tools.

One of the most significant features of the building is the high number of disarticulated human remains deposited under the floors of Space 50, currently being studied by Dr Sam Walsh (Fig. 6). At least 55 individuals, many of them children and infants, have so far been excavated from Space 50. Grave goods in the form of beads of dentalium, clay, crab claw and, rarely, carnelian and jasper, were deposited with the human remains. We recovered two cowrie shells in close proximity to one human skull. The large number of interred individuals, mainly in the form of secondary burials, suggests that Building 5 had a social significance well beyond that of a single resident family.

\section{Bestansur, Trenches 12-13}

In Trenches 12-13, at the northern edge of the mound, we excavated Neolithic architecture and finely stratified deposits (Fig. 2). A single radiocarbon date from Trench 13 indicates that the latest of at least three phases of occupation here may date to $c .7100 \mathrm{BC}$, approximately 500 years later than the Trench 10 occupation (Fig. 4). Earlier architecture in Trenches 12-13 comprises small rooms bounded by pisé walls (Fig. 7) with some external spaces. We found significant quantities of fish bones and possible stone net-weights in this part of the site, in marked contrast to other trenches at Bestansur.

\section{Chipped stone assemblages from Bestansur}

Chipped stone tools and debitage were recovered in large quantities from all trenches at Bestansur. The tool assemblage attested at Bestansur can be broadly characterised as Mlefatian as defined by Kozlowski (1999), with an emphasis on blades and bladelets, and production of a repertoire of tool types on locally available cherts with usage of imported obsidian. Blades occur in large numbers, and the vast majority of them are broken at either one or both ends. All blade tools may have been used for a wide variety of cutting and slicing activities. Apart from blades and tools made on blades, other tool types include scrapers, drills, and borers. There are rare occurrences of microliths in the form of trapezes and crescents. A common tool form at Bestansur is the diagonal-ended bladelet, which is likely to have been set into a bone or wooden haft to serve as a barb, perhaps for fishing or spearing small game.

One of the most diagnostic tool types found at Bestansur is the so-called Çayönü tool (Fig. 8). These tools have a distinctive morphology, with thick blades showing steep, dense retouch on both edges, and often with a flaring or hooked end. In cross-section they are frequently angular and rhomboid. On their flat obverse faces they often show clear use-wear traces in the form of radial lines etched into the obsidian, interpreted by Anderson (1994) as evidence for their use in final finishing or decorating of stone objects such as marble bracelets and limestone plaques or bowls. Çayönü tools appear in a broad band of territory spanning southeast Anatolia, upper Mesopotamia and the central Zagros, and are dated to the later eighth and seventh millennia calibrated BC (Kozlowski and Aurenche 2005, 143). At Çayönü itself these tools are associated in particular with the Cell Building and subsequent sub-phases (Caneva et al. 1994, 263), from c. 7600 calibrated BC onwards.

\section{Excavations at Shimshara}

The site of Shimshara was selected for excavation within the remit of CZAP as it was known to have Neolithic levels from Mortensen's (1970) excavations in the 1950s. Shimshara is located on the Rania Plain (Fig. 1) in Sulaimaniyah Province, the second most fertile plain in Iraqi Kurdistan after the Shahrizor Plain. Since the late 1950s and the construction of the Dokan Dam, Shimshara has been periodically flooded according to seasonal water levels. At the moment, the site is at least periodically above water and accessible for excavation for part of each year. Located on a large fertile plain, $110 \mathrm{~km}$ northwest of Bestansur, Shimshara participated 


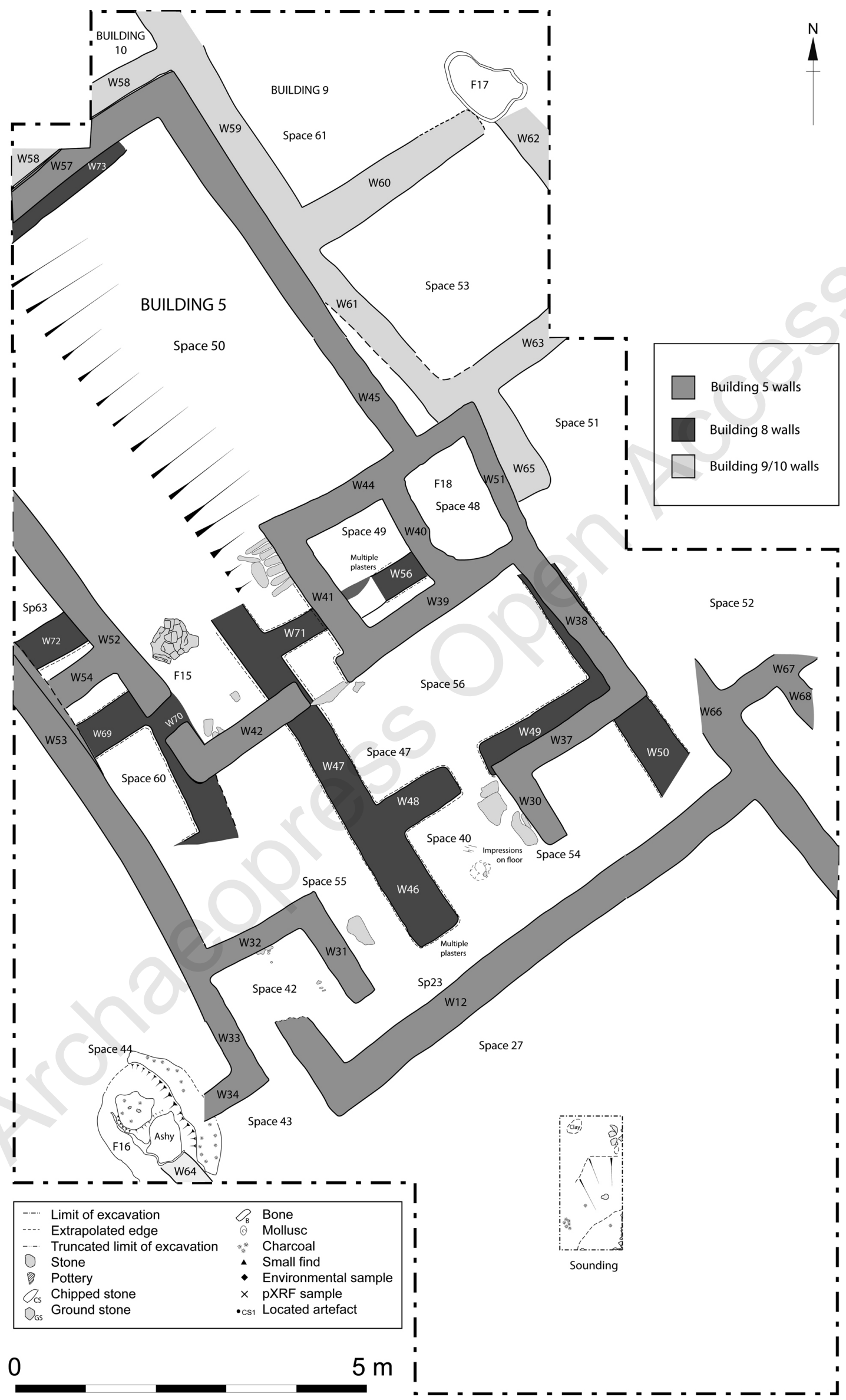

Figure 3. BeStANSUR, TRENCH 10 COMPOSite PLAN OF ARCHITECTURE. 


\begin{tabular}{|c|c|c|c|c|c|c|c|}
\hline Site & Trench & $\begin{array}{c}\text { Context } \\
\text { no. }\end{array}$ & Material & Lab no. & $\begin{array}{c}\text { Conventional } \\
\text { date BP }\end{array}$ & $\begin{array}{c}\text { Intercept with } \\
\text { calibration curve } \\
\text { Cal BC }\end{array}$ & $\begin{array}{l}\text { Calibrated date } B C \\
2 \text { sigma }(95.4 \%)\end{array}$ \\
\hline Bestansur & 5 & 1078 & Mollusc shell & Beta-326883 & $9570 \pm 40$ & $9120-8840$ & $\begin{array}{c}9170-9160 \text { and } \\
9160-8780\end{array}$ \\
\hline Bestansur & 10 & 1772 & Animal bone & Beta-406556 & $8620 \pm 30$ & 7595 & $7645-7585$ \\
\hline Bestansur & 10 & 1412 & Goat tibia & Beta-368934 & $8610 \pm 50$ & 7600 & $7720-7580$ \\
\hline Bestansur & $12-13$ & 1386 & Pig carpal & Beta-408868 & $8130 \pm 30$ & 7075 & 7175-7055 \\
\hline Shimshara & Section & & Pistacia sp. & Beta-342484 & $8230 \pm 40$ & $\begin{array}{c}7300 \text { and } \\
7220 \text { and } \\
7190\end{array}$ & $\begin{array}{c}7450-7440 \text { and } \\
7420-7410 \text { and } \\
7360-7120 \text { and } \\
7110-7080\end{array}$ \\
\hline
\end{tabular}

FigurE 4. RADIOCARBON DATES FROM BESTANSUR AND SHIMSHARA.

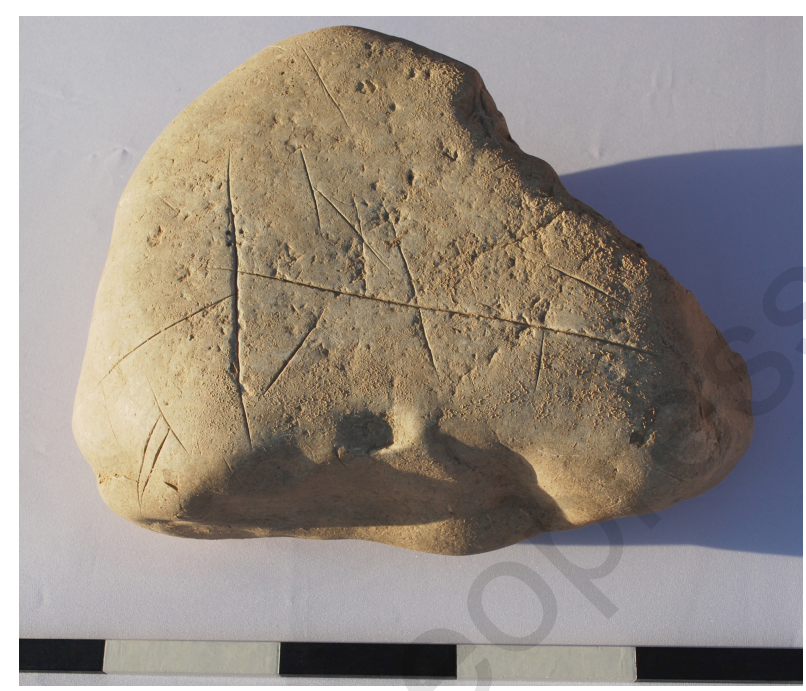

Figure 5. LARgE StONE AT ENTRANCE to BUILDING 5.

in different regional networks and thus provides an important comparison to Bestansur, for investigation of local and regional variation in Neolithic ecological and social strategies, a key CZAP research issue. Bestansur is close to a perennial spring while Shimshara is on the banks of a major river, the Lesser Zab (Fig. 9).

Initial assessment of the Neolithic levels at Shimshara established that there are at least $2.5 \mathrm{~m}$ depth of extant Neolithic deposits above natural. A radiocarbon date on charred plant material from the base of our excavations indicates occupation at c. 7300-7200 BC (Fig. 4). Two trenches were excavated at Shimshara in 2012-13 (Fig. 10). An important discovery is the identification of grey silty clay deposits with well-preserved plant remains that represent the earliest activities in this area of the site. Neolithic occupation and activities in Trench 1 include a flat working area at the edge of a break in slope, and adjacent discard deposits containing burnt stones, aggregates and animal bones. In Trench 2, the earliest excavated deposits represent diverse activities on a series of small pebble and stone surfaces, with artefact fragments such as carved marble bracelet fragments and an incised stone bowl sherd. In future investigations it would be valuable to extend excavations to the west of Trench 1 to enable open-area excavation of Neolithic levels.

The chipped stone assemblage from Shimshara includes a much greater representation of obsidian, with multiple Çayönü tools (Fig. 8). Sickle blades are also well represented, and there are examples of diagonal-ended bladelets in chert and obsidian.

\section{Conclusions: exploring the Neolithic of the eastern Fertile Crescent}

In addition to the issues discussed above, CZAP specialists are currently studying the full range of material culture and ecological evidence from the sites of Bestansur and Shimshara, including architecture, stratigraphy, micro-archaeology, animal bones, human remains, charred plants, ground-stone, chipped stone, clay objects, networks of material and resource use, radiocarbon dating, and molluscs. The CZAP team is currently preparing reports and analyses of all these aspects for publication as volume 2 of the project's final publications. Additionally, an ambitious plan of local 


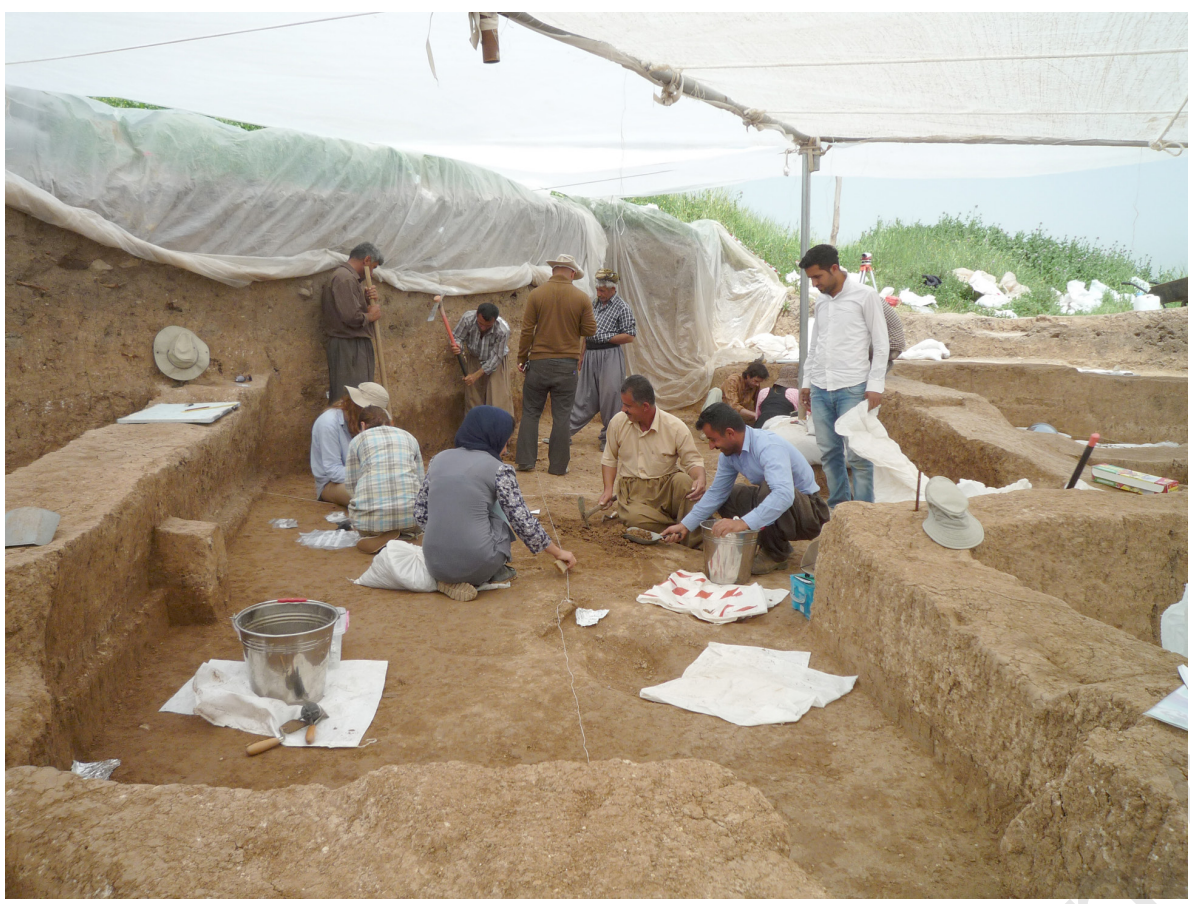

FIGURE 6. EXCAVATION OF HUMAN REMAINS FROM BUILDING 5, SPACE 50.

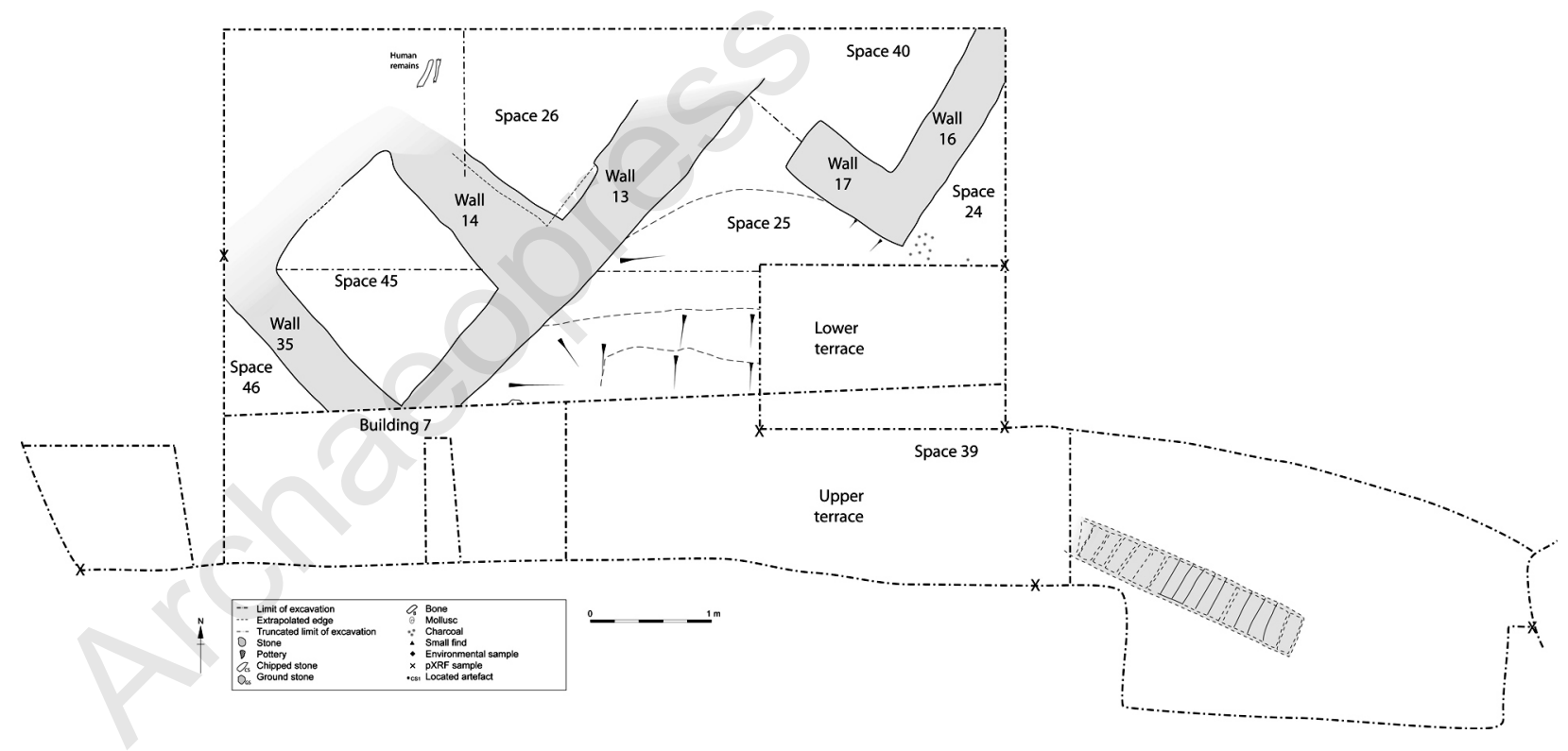

Figure 7. Bestansur, TRENCHES 12-13 ARCHITECTURE.

and regional outreach and engagement is being planned in consultation with colleagues in Sulaimaniyah and beyond.
For the first time, our excavations at Bestansur and Shimshara are shedding light on the Pre-Pottery Neolithic period of the eastern Fertile Crescent, in particular during 


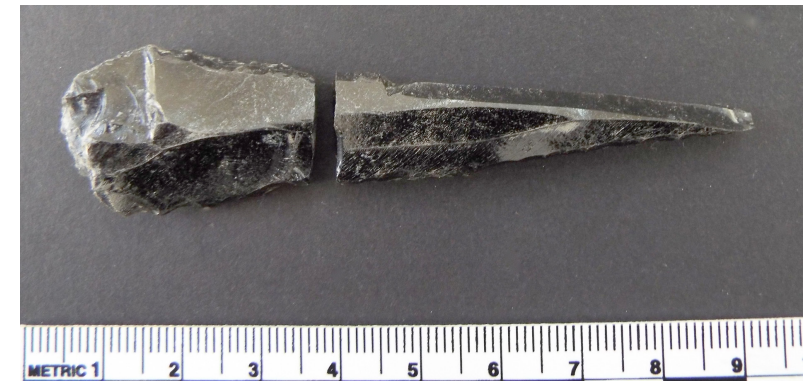

FIGURE 8. OBSIDIAN ÇAYÖNÜ TOOL FROM SHIMSHARA, RE-USED AS BLADE CORE. the eighth millennium BC. Excavated levels at both sites pre-date and are contemporary with the earliest Neolithic levels excavated by Braidwood at Jarmo, in the same region, and they provide new insights into the origins of sedentism, the early development of sophisticated architecture, the elaboration of human burial practices, the engagement of local communities in networks of trans-regional interaction, and local diversity in ecological, environmental and social pathways through the transition from hunter-forager to villager-herder.

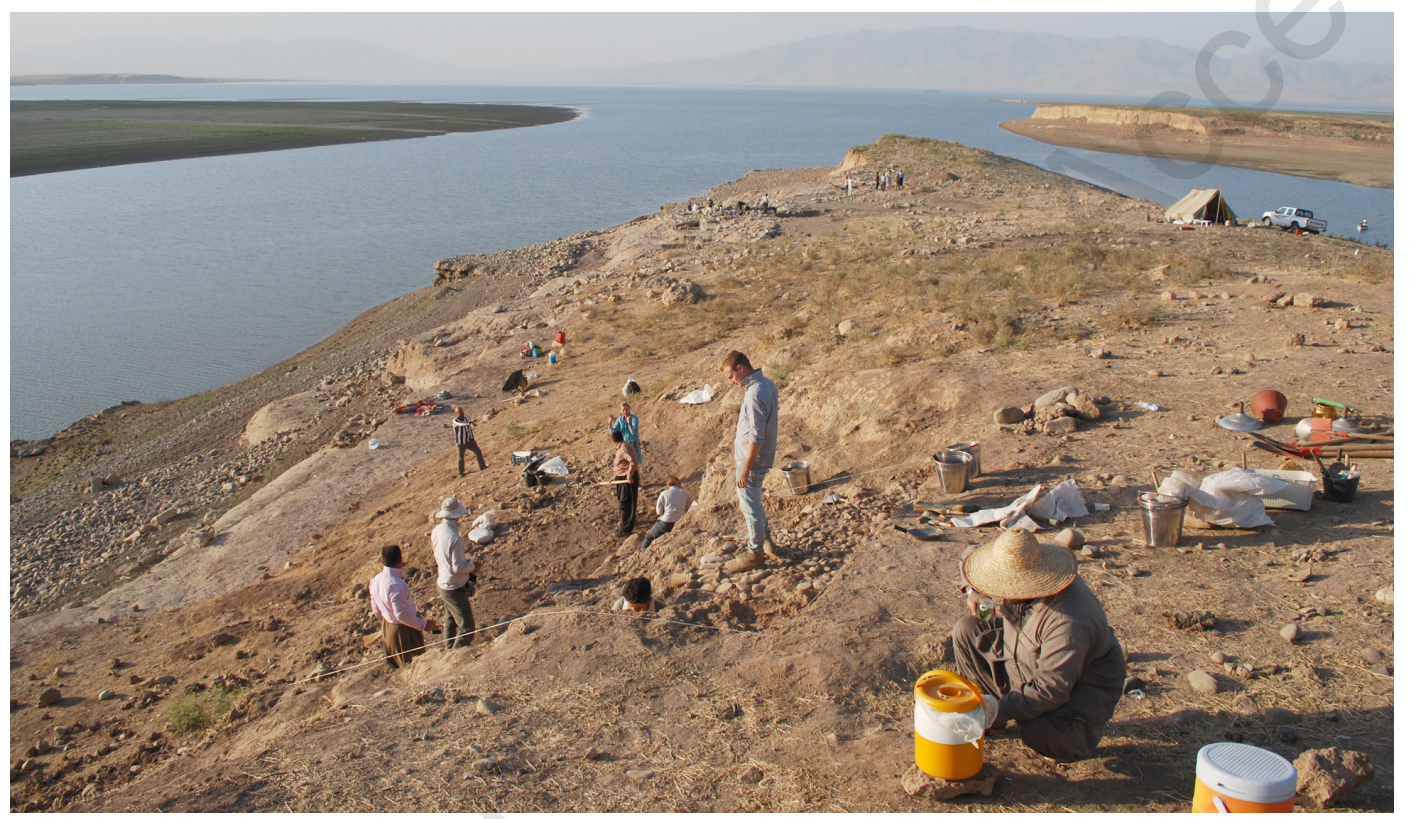

Figure 9. VieW of SHIMShara, Looking SOUth to the Dokan DAM lake.

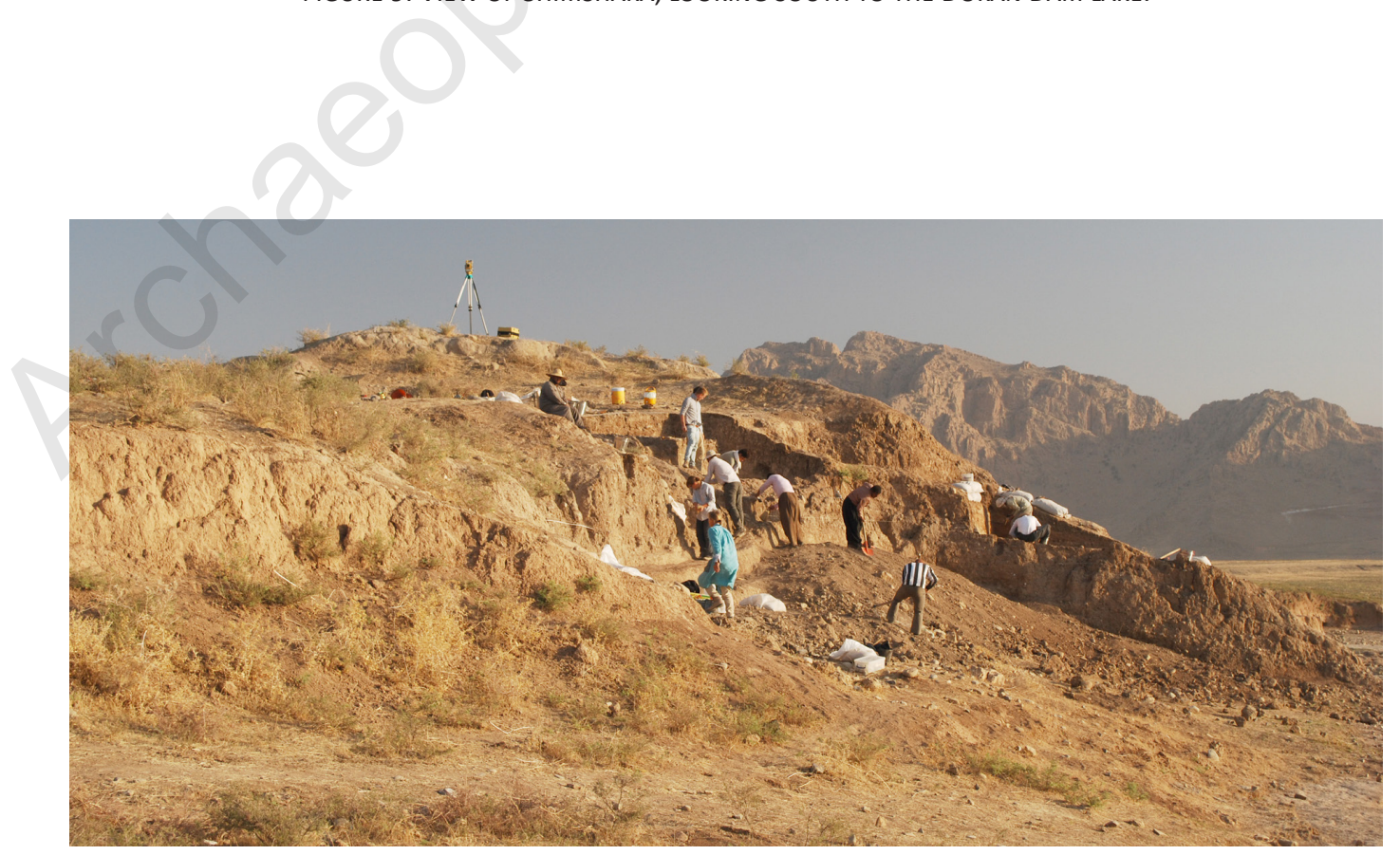

Figure 10. Shimshara, LoCATION OF TRENCH 1 (LEFT) AND TRENCH 2 (RIGHT), LOOKING NORTH. 


\section{Acknowledgements}

The project operates under a Memorandum of Understanding issued by the Sulaimaniyah and Erbil Directorates of Antiquities and Heritage, with agreement from the State Board of Antiquities and Heritage, Baghdad, and is currently funded by a grant from the UK Arts and Humanities Research Council (AHRC, 20112015) with the project title 'Sedentism and Resource Management in the Neolithic of the Central Zagros'.

We are extremely grateful to all our colleagues at Sulaimaniyah Directorate of Antiquities and Heritage, under its Director Kamal Rasheed Raheem, who made the project possible and provided vital support at every stage, as well as all the support staff and drivers. We also thank our colleagues at Erbil Directorate of Antiquities and Heritage, in particular its Director, Abubakir O. Zainadin (Mala Awat), for their ongoing support. We are very appreciative also of the considerable assistance provided by the staff of Sulaimaniyah Museum, led by its Director, Hashim Hama Abdullah. Our government representatives, Sabr Ahmed Sabr and Kamal Raouf Aziz, gave support and advice in a great many ways as well as serving as key team members. We thank the villagers of Bestansur who worked with us on site and looked after us in the Expedition House. We also are very grateful to all who have served on the CZAP team.

Finally, we express our sincere thanks to Dr John MacGinnis and Dr Kostantinos Kopanias for organising a highly productive conference in Athens in November 2013.

\section{Bibliographical References}

Altaweel, M., A. Marsh, S. Mühl, O. Nieuwenhuyse, K. Radner, K. Rasheed, and S. A. SABer. 2012. 'New investigations in the environment, history, and archaeology of the Iraqi hilly flanks: Shahrizor survey project 2009-2011.' Iraq 74:1-35.

ANDERSON, P. C. 1994. 'Reflections on the significance of two PPN typological classes in light of experimentation and microwear analysis: flint "sickles" and obsidian "Çayönü tools".' In Neolithic Chipped Stone Industries of the Fertile Crescent, edited by H. G. Gebel, and S. K. Kozlowski: 61-82. Berlin: ex oriente.

Bernbeck, R. 2004. 'Iran in the Neolithic.' In Persiens Antike Pracht: Bergbau, Handwerk, Archäologie, edited by T. Stöllner, R. Slotta, and A. Vatandoust: 140-8. Bochum: Deutsches Bergbau-Museum.

Braidwood, R. J., and B. Howe. 1960. Prehistoric Investigations in Iraqi Kurdistan. Chicago: University of Chicago Press.

Caneva, I., A. M. Conti, C. Lemorini, and D. Zampetti. 1994. 'The lithic production at Çayönü: a preliminary overview of the aceramic sequence.' In Neolithic Chipped Stone Industries of the Fertile Crescent, edited by H. G. Gebel, and S. K. Kozlowski: 253-66. Berlin: ex oriente.

HodDER, I. (ed.). 2010. Religion in the Emergence of Civilization: Çatalhöyük as a Case Study. Cambridge: Cambridge University Press.

Hole, F., K. V. Flannery, and J. A. Neely. 1969. Prehistory and Human Ecology of the Deh Luran Plain: an Early Village Sequence from Khuzistan, Iran. Ann Arbor: University of Michigan.

Kozlowski, S. K. 1999. The Eastern Wing of the Fertile Crescent: Late Prehistory of Greater Mesopotamian Lithic Industries. Oxford: British Archaeological Reports.

Kozlowski, S. K., and O. Aurenche. 2005. Territories, Boundaries and Cultures in the Neolithic Near East. Oxford: British Archaeological Reports.

Kuist, I. (ed.). 2000. Life in Neolithic Farming Communities: Social Organization, Identity, and Differentiation. New York: Kluwer Academic and Plenum Press.

Matthews, R., W. Matthews, and Y. Mohammadifar. (eds.). 2013. The Earliest Neolithic of Iran. 2008 Excavations at Sheikh-e Abad and Jani. Oxford: Oxbow.

Matthews, R., and H. Fazeli Nashli. (eds.). 2013. The Neolithisation of Iran. The Formation of New Societies. Oxford: Oxbow.

Mortensen, P. 1970. Tell Shimshara. The Hassuna Period. Copenhagen: Det Kongelige Danske Videnskabernes Selskab.

Nieuwenhuyse, O., K. Berghuis, and S. MüHL. 2012. 'A late Neolithic "fishing net" from Kurdistan, northern Iraq?' Paléorient 38:141-7.

Riehl, S., M. ZEIDI, and N. J. ConARD. 2013. 'Emergence of agriculture in the foothills of the Zagros mountains of Iran.' Science 341:65-7.

Smith, P. E. L. 1990. 'Architectural innovation and experimentation at Ganj Dareh, Iran.' World Archaeology 21:323-35.

WASYlikowA, K., and A. WitKowski. (eds.). 2008. The Palaeoecology of Lake Zeribar and Surrounding Areas, Western Iran, during the Last 48,000 Years. Ruggell: Gantner.

Willcox, G. 2005. 'The distribution, natural habitats and availability of wild cereals in relation to their domestication in the Near East: multiple events, multiple centres.' Vegetation History and Archaeobotany 14:534-41.

ZEDER, M. A. 2006. 'A critical assessment of markers of initial domestication in goats (Capra hircus).' In Documenting Domestication: New Genetic and Archaeological Paradigms, edited by M. A. Zeder, D. Bradley, E. Emschwiller, and B. D. Smith: 181206. Berkeley: University of California.

ZEDER, M. A. 2011. 'The origins of agriculture in the Near East.' Current Anthropology 52:221-35. 